https://doi.org/10.35339/msz.2019.82.01.06

УДК 611-018.26:616-008.9

\author{
G.D. Fadieienko, Ya.V. Nikiforova
}

Government Institution «L.T. Malaya Therapy National Institute of the National Academy of Medical Sciences of Ukraine», Kharkiv

\title{
METABOLIC ROLE OF VISCERAL ADIPOSE TISSUE AND MAIN METHODS OF ITS DIAGNOSIS AT THE PRESENT STAGE
}

\begin{abstract}
A review of the literature on the metabolic role of visceral adipose tissue and the main methods for its diagnosis is presented. Visceral adipose tissue is an active endocrine organ what secretes a number of biologically active substances. With an increase in the proportion of visceral adipose tissue, moderate inflammation is observed with a chronic systemic increase in the activity of adipokines. Adipokines carry out several immune or metabolic functions associated with inflammatory infiltration. Active substances such as leptin, adiponectin, resistin, etc., the source of which is visceral adipose tissue, have peripheral, central and local effects on the metabolism of glucose and lipids, glycolysis processes in the liver, etc. It is the activity of visceral adipose tissue that should be considered among the main pathophysiological development factors obesity and its potential metabolic cardiovascular and/or liver complications.
\end{abstract}

Keywords: visceral adipose tissue, chronic systemic inflammation, insulin resistance, metabolic disorders.

At the present stage, visceral adipose tissue (VAT) is considered as an active endocrine organ, which produces a number of biologically active substances. Visceral adipose tissue is highly sensitive to the lipolytic action of catecholamine's and is low-susceptible to the antilipolytic action of insulin, in contrast to subcutaneous adipose tissue, has better innervations and blood supply. With an increase in the proportion of VAT, moderate inflammation with a chronic systemic increase in the activity of adipokines, which carry several immune or metabolic functions associated with inflammatory infiltration, is observed. A number of active substances (leptin, adiponectin, resistin, etc.), the source of which is VAT, have a peripheral, central and local influence on the metabolism of glucose and lipids, liver glycolysis processes, and the like.
Visceral adipose tissue normally in metabolically healthy people does not exceed the index of $8-10 \%$ in contrast to the indicators of hypodermic adipose tissue (normally about $90 \%$ ). While hypodermic adipose tissue serves as an energy depot, VAT performs the role of the active endocrine organ that produces a number of biologically active substances known as adipocytokines or adipokines [1]. Leptin, adiponectin, resistin, estrogens, adipokine, angiotensinogen, eicosanoids, steroids, etc., the source of which are VAT, influence on mechanisms of hunger, appetite, absorption and metabolism of glucose, lipids, processes of liver glycolysis, etc.

Visceral obesity is closely linked to an increased risk of insulin resistance, diabetes mellitus type 2, dyslipidemia, hypertension, non-

(C) G.D. Fadieienko, Ya.V. Nikiforova, 2019 
alcoholic fatty liver disease, and other components of the metabolic syndrome.

According to the research, with an increase in the percentage of VAT, there is even a «low grade» of inflammation, but with a chronic systemic increase in the group of molecules (adipokines), which, in addition to pro- or antiinflammatory actions, carry out several immune or metabolic functions associated with macrophage infiltration in VAT [1-3]. These two factors provide a deeper understanding of the pathophysiology of obesity and its potential metabolic cardiovascular or hepatic complications $[2,4,5]$. A small or even moderate weight loss significantly reduces the number of circulating inflammatory markers, regulates the profile of proinflammatory adipose tissue genes and the risks associated with obesity and other metabolic diseases [6].

One of the important reasons for the accumulation of excessive VAT is a nutritional disorder. In conditions of high intake of food rich in fats and light carbohydrates, the secretion of insulin, which, in turn, activates lipogenesis and deposition of free fatty acids in the adipose tissue, is stimulated. However, there is a genetically determined limit of the ability of adipose tissue to accumulate lipids, so the excess of free fatty acids through the reverse vein begins to enter the liver (increases the synthesis of triglycerides, the accumulation of which more than $5 \%$ of the mass of the body is treated as steatosis of the liver). The result of chronic high free fatty acids in the liver is the activation of lipid peroxide oxidation, resulting in a large amount of active forms of oxygen produced, oxidative stress that promotes the transformation of liver steatosis into steatohepatitis and these factors lead to the phosphorylation of the insulin receptor substrates. Thus, hepatic resistance to insulin is triggered, i. e., there is a peculiar vicious circle [7].

The increased intake of free fatty acids (or their precursors) to the liver may be observed with an elevated hyperlipidemia caused by excessive consumption of fats or a rapid loss of adipose tissue during fasting. The increase in their synthesis occurs due to excessive intake of glucose in the liver, which also serves as a source for the formation of triglycerides [8,9]. It has been shown that insulin resistance is due to the accumulation of triglycerides in non-fatty tissue cells, mainly in the liver and skeletal muscle.
Decrease of the processes of withdrawal of triglycerides from the liver occurs as a result of a decrease in the synthesis of transport systems $[10,11]$.

Adiponectin plays an important role in lipid and glucose metabolism, which is synthesized only by adipose tissue and whose level in obese patients is lowered recent years [11]. Studies have shown that low levels of adiponectin in the blood precede the development of insulin resistance. A direct relationship was found between the level of adiponectin and the risk of developing diabetes mellitus type 2 and an atherogenic blood profile [2]. Adiponectin exhibits antiatherogenic effect by reducing platelet adhesion to the endothelium, suppressing the transformation of macrophages in foam cells, and proliferation and migration of myocytes. Adiponectin reduces the supply of VAT in the liver and stimulates their oxidation, and thus contributes to reducing liver glucose, triglycerides, low density lipoproteins. Adiponectin stimulates the oxidation of free fatty acids in muscle tissue, preventing its placement in the muscles, improves the sensitivity of muscle tissue to insulin $[3,4$, 9-11].

Increasing the percentage of VAT and imbalance of immunomodulatory proteins (adipokines) is considered to be the key link in the development of cardiovascular diseases (hypertension, atherosclerosis, myocardial infarction). A number of researchers are considering predicting the course of the cardiovascular diseases not the body mass index, namely the area or percentage of VAT $[5,6,10]$. The adipose tissue synthesizes angiotensin, which, under the influence of renin and angiotensin-converting enzyme, is converted into angiotensin II, which causes vasospasm and stimulates the synthesis of triglycerides [8,9]. An increase in the percentage of high density lipoproteins is accompanied by chronic elevated synthesis of angiotensin II, which leads to increased blood pressure and development of hypertension.

Recent researches have shown that the increase in VAT area is due to the increase of the cardiovascular risk. Thus, in men, the VAT plane, exceeding the $131 \mathrm{~cm}^{2}$ index, was associated with an increased risk of cardiovascular diseases $[5,6,11]$. A number of researchers have shown the effect of VAT on cardiovascular risk in patients with normal body mass due to the highest mortality risk of this group. It has been 
established that in people with normal body mass and visceral obesity of the cardiovascular risk it is higher in 2,75 times, and the risk of death from all causes is 2,08 , than in people with normal body weight without visceral obesity [7]. At the present stage, the visceral abdominal tissue and abdominal subcutaneous adipose tissue are considered as new biomarkers of metabolic disorders $[9,10]$.

Studies of the last decades have shown the need to separate the concepts of «abdominal obesity», which is diagnosed when the WHO indicators are exceeded and "visceral obesity», which is diagnosed with an increase in the number of VAT $[6,7]$.

Japanese and Korean researchers have published data on the possibility of evaluating the quantitative indicators of VAT by means of computer tomography and introduced their method of analysis of the coefficient of VAT / PAT. They proved that the ratio of the planes of intraabdominal VAT to PAT is closely related to carbohydrate and fat metabolism disorders in obese people. These metabolic rates were significantly higher in the so-called «visceral» group (with VAT / PAT level not less than 0,4), compared to those in the «subcutaneous» group (with VAT / PAT level less than 0,4) [2, 7]. The same authors found in the «visceral» group the independence of carbohydrate and lipid metabolism disorders from gender, age and body mass index. In addition to the quantitative indicators of visceral fat, the quality of health affects the functional state of VAT, and the risk of metabolic disorders affects its dysfunction $[1,2]$.

M.C. Amato and co-authors [4] proposed a new calculation for the determination of the visceral adiposity index associated with cardiovascular risk-associated dysfunction. This gender-specific index uses both anthropometric measurements (body mass index, waist circumference) and metabolic parameters (triglycerides, high density lipoproteins), which simultaneously takes into account the distribution pattern and metabolic function of adipose tissue. The calculation of visceral adiposity index provides an opportunity to estimate individual deviations from the norm of constitutional and metabolic indicators in the patients under investigation [8]. It has been shown that unlike the previous classical markers (waist circumference, body mass index, etc.) taken alone, visceral adiposity index is independently associated with all factors of metabolic disturbances [7]. Visceral adiposity index uses both physical and metabolic parameters which are indirect reflection of other nonclassical risk factors, such as changes in the production of adipocytokines, lipolysis, increased free fatty acids in blood plasma, which are not detected with a separate definition of body mass index, waist circumference, triglycerides, high density lipoproteins. That is why visceral adiposity index can be an integral indicator of the functioning of VAT $[7,8]$. The value of visceral adiposity index $>1$ was considered as the presence of dysfunction VAT.

It should be noted that as a violation of the diet can affect the percentage of VAT, and the presence of visceral obesity can change the eating behavior. Recent studies have shown that the central (abdominal) type of obesity, and not the increase in total body fat, is an important risk factor for the development of eating disorders, namely loss of control during meals. Many researchers view obesity as a result of pathological behavioral reflex: they feel saturated only when consuming the entire portion of food, regardless of its size, while decreasing portions from the usual to the required reduces the use of excess calories per day for 16-29\% [8]. In a study by L.A. Berner et al. [6] it was determined that with an increase in 1 unit of VAT volume in the abdomen, the risk of uncontrolled overeating in the future increases by $53 \%$ [6]. This study emphasizes the close relationship between the features of eating disorders and the percentage of metabolic active VAT.

\section{Conclusions}

Thus, visceral fatty tissue is an active endocrine organ that produces a number of biologically active substances. With an increase in the proportion of VAT, moderate inflammation with a chronic systemic increase in the activity of adipokines, which carry several immune or metabolic functions associated with inflammatory infiltration, is observed. A number of active substances, the source of which is VAT, have a peripheral, central and local influence on the metabolism of glucose and lipids, liver glycolysis processes, and the like.

Exactly VAT activity should be considered among the main pathophysiological promising factors of the development of obesity and its potential metabolic cardiovascular or hepatic complications. 


\section{References}

1. Galic S., Oakhill J.S., Steinberg G.R. (2010). Adipose tissue as an endocrine organ. Mol. Cell. Endocrinol., vol. 316, pp. 129-139.

2. Abraham T.M., Pedley A., Massaro J.M., Hoffmann U., Fox C.S. (2015). Association between visceral and subcutaneous adipose depots and incident cardiovascular disease risk factors. Circulation, vol. 132 (17), pp. 1639-1647.

3. Ahonen T.M., Saltevo J.T., Kautiainen H.J., Kumpusalo E.A., Vanhala M.J. (2012). The association of adiponectin and low-grade inflammation with the course of metabolic syndrome. Nutr. Metab. Cardiovasc. Dis., vol. 22, pp. 285-291.

4. Amato M.C., Giordano C., Galia M., Criscimanna A., Vitabile S., Midiri M. et al. (2010). Visceral adiposity index. A reliable indicator of visceral fat function associated with cardiometabolic risk. Diab. Care, vol. 33 (4), pp. 920-922.

5. Rodriguez-Hernandez H., Simental-Mendia L.E., Rodriguez-Ramirez G., Reyes-Romero M.A. (2013). Obesity and inflammation: epidemiology, risk factors, and markers of inflammation. Int. J. Endocrinol., vol. 3, pp. 1-11.

6. Berner L.A., Arigo D., Mayer L.E., Sarwer D.B., Lowe M.R. (2015). Examination of central body fat deposition as a risk factor for loss-of-control eating. The American Journal of Clinical Nutrition, vol. $102(4)$, pp. 736.

7. Chen S.H., He F., Zhou H.L., Wu H.R., Xia C., Li Y.M. (2011). Relationship between nonalcoholic fatty liver disease and metabolic syndrome. J. Digestive Diseases, vol. 12, pp. 125-130.

8. European Association for the Study of the Liver, European Association for the Study of Diabetes, European Association for the Study of Obesity. (2016). EASL-EASD-EASO Clinical Practice Guidelines for the management of non-alcoholic fatty liver disease. Obesity Facts, vol. 9, № 2, pp. 65-90.

9. Gariani K., Jornayvaz F. (2013). Non-alcoholic fatty liver disease and insulin resistance: From bench to bedside. Diabetes \& Metabolism, vol. 16, pp. 130-137.

10. Jung U.J., Choi M.S. (2014). Obesity and its metabolic complications: the role of adipokines and the relationship between obesity, inflammation, insulin resistance, dyslipidemia and nonalcoholic fatty liver disease. Int. J. Mol. Sci., vol. 15 (4), pp. 6184-6223.

11. Musso G. (2012). Nonalcoholic steatohepatitis versus steatosis: adipose tissue insulin resistance and dysfunctional response to fat ingestion predict liver injury and altered glucose and lipoprotein metabolism. Hepatol., vol. 56 (3), pp. 933-942.

\section{Г.Д. Фадеенко, Я.В. Никифорова \\ МЕТАБОЛИЧЕСКАЯ РОЛЬ ВИСЦЕРАЛЬНОЙ ЖИРОВОЙ ТКАНИ И ОСНОВНЫЕ МЕТОДЫ ЕЕ ДИАГНОСТИКИ НА СОВРЕМЕННОМ ЭТАПЕ}

Представлен обзор литературы, касающейся вопросов метаболической роли висцеральной жировой ткани и основных методов ее диагностики. Висцеральная жировая ткань - активный эндокринный орган, который секретирует ряд биологически активных веществ. При увеличении доли висцеральной жировой ткани наблюдается умеренное воспаление с хроническим системным повышением активности адипокинов. Последние осуществляют несколько иммунных или метаболических функций, связанных с воспалительной инфильтрацией. Такие активные вещества, как лептин, адипонектин, резистин и т. п., источником которых является висцеральная жировая ткань, оказывают периферическое, центральное и местное влияние на метаболизм глюкозы и липидов, процессы гликолиза в печени и др. Именно активность висцеральной жировой ткани следует рассматривать среди главных патофизиологических факторов развития ожирения и его потенциальных метаболических сердечно-сосудистых и/или печеночных осложнений.

Ключевые слова: висиеральная жировая ткань, хроническое системное воспаление, инсулинорезистентность, метаболические нарушения. 


\section{Г.Д. Фадєєнко, Я.В. Нікіфорова \\ МЕТАБОЛІЧНА РОЛЬ ВІСЦЕРАЛЬНОЇ ЖИРОВОЇ ТКАНИНИ ТА ОСНОВНІ МЕТОДИ ÏЇ ДІАГНОСТИКИ НА СУЧАСНОМУ ЕТАПІ}

Подано огляд літератури, що стосується питань метаболічної ролі вісцеральної жирової тканини та основних методів ііі діагностики. Вісцеральна жирова тканина - активний ендокринний орган, який виробляє низку біологічно активних речовин. При збільшенні частки вісцеральної жирової тканини спостерігається помірне запалення з хронічним системним підвищенням активності адипокінів. Останні здійснюють кілька імунних або метаболічних функцій, пов'язаних із запальною інфільтрацією. Такі активні речовини, як лептин, адипонектин, резистин тощо, джерелом яких є вісцеральна жирова тканина, справляють периферичний, центральний та локальний вплив на метаболізм глюкози й ліпідів, процеси гліколізу в печінці тощо. Саме активність вісцеральної жирової тканини слід розглядати серед головних патофізіологічних чинників розвитку ожиріння та його потенційних метаболічних серцево-судинних та/або печінкових ускладнень.

Ключові слова: вісиеральна жирова тканина, хронічне системне запалення, інсулінорезистентність, метаболічні порушення.

Надійшла 27.02.19

\section{Відомості про авторів}

Фадєєнко Галина Дмитрівна - доктор медичних наук, професор, директор ДУ «НІТ ім. Л.Т. Малої НАМН України».

Адреса: 61039, м. Харків, пр. Любові Малої, 2а, ДУ «НІТ ім. Л.Т. Малої НАМН України». Тел.: +38(057)370-90-16.

E-mail: therapy@amnu.gov.ua.

ORCID: https://orcid.org/0000-0003-0881-6541.

Нікіфорова Яна Василівна - кандидат медичних наук, науковий співробітник відділу вивчення захворювань органів травлення та їх коморбідності з неінфекційними захворюваннями ДУ «НІТ ім. Л.Т. Малої НАМН України».

Адреса: 61039, м. Харків, пр. Любові Малої, 2а, ДУ «НІТ ім. Л.Т. Малої НАМН України». Тел.: +38(068)611-11-22.

E-mail:dr.Jana@email.ua.

ORCID: https://orcid.org/0000-0002-0792-1377. 